\title{
вмј Global Health Search without rescue? Evaluating the international search and rescue response to earthquake disasters
}

\author{
Anna Rom (D) , ${ }^{1}$ Ilan Kelman ${ }^{2,3}$
}

To cite: Rom A, Kelman I. Search without rescue? Evaluating the international search and rescue response to earthquake disasters. BMJ Global Health 2020;5:e002398. doi:10.1136/ bmjgh-2020-002398

Handling editor Eduardo Gómez

- Additional material is published online only. To view please visit the journal online (http://dx.doi.org/10.1136/ bmjgh-2020-002398).

Received 18 February 2020 Revised 13 September 2020 Accepted 11 November 2020

Check for updates

(c) Author(s) (or their employer(s)) 2020. Re-use permitted under CC BY-NC. No commercial re-use. See rights and permissions. Published by BMJ.

${ }^{1}$ UCL Institute for Global Health, London, UK

${ }^{2}$ UCL Institute for Global Health and UCL Institute for Risk and Disaster Reduction, London, UK ${ }^{3}$ University of Agder, Kristiansand, Norway

Correspondence to Prof llan Kelman;

ilan_kelman@hotmail.com

\section{ABSTRACT}

Earthquakes around the world are unnecessarily lethal and destructive, adversely affecting the health and wellbeing of affected populations. Most immediate deaths and injuries are caused by building collapse, making search and rescue (SAR) an early priority. In this review, we assess the SAR response to earthquake disasters. First, we review the evidence for the majority of individuals being rescued locally, often by relatives and neighbours. We then summarise evidence for successful live rescues by international SAR (ISAR) teams, along with the costs, ethics and other considerations of deployment. Finally, we propose an alternative approach to postdisaster ISAR, with the goal of reducing overall morbidity and mortality.

\section{INTRODUCTION}

In the last 20 years, earthquakes have affected 125 million people, leading to around 750 000 deaths. $^{12}$ The threat from earthquakes disproportionately affects poorer countries, where lack of building standards and ineffective response infrastructure often coexist. ${ }^{3}$

The most common cause of earthquakerelated casualties is building collapse. ${ }^{4-6}$ Search and rescue (SAR) is therefore an immediate priority. SAR is defined as the location and extraction of trapped individuals, either informally by relatives and neighbours or formally by professional local or intentional teams. As some countries lack professional teams, or adequate capacity, international SAR (ISAR) teams frequently respond.

Prior to 1985, earthquake ISAR teams did not formally exist, with ad hoc response from international specialists to some events. ${ }^{7}$ After the 1985 earthquake in Mexico City, the combination of collapse of multiple reinforced concrete buildings, and the advent of 24-hour news beaming pictures of the devastation around the world, led to several SAR teams, usually only operating domestically in their home counties, deploying internationally. $^{89}$

\section{Key questions}

What is already known?

- The most common cause of earthquake-related casualties is building collapse, making early search and rescue a priority.

- There is often a lot of media and public interest in international search and rescue operations following earthquake disasters.

- The majority of search and rescue is carried out locally in the immediate aftermath of earthquakes.

What are the new findings?

- International search and rescue teams arrive too late to make a significant contribution to lives saved.

- International search and rescue is expensive in comparison to training and preparing locals.

What do the new findings imply?

- Investing in equipping and training local teams in high risk, vulnerable earthquake-prone areas may save more lives.

- Further research is needed to evaluate how best to deliver such training and who best to receive it.

The results were chaotic, with different teams arguing over how to perform rescues, time wasted repeatedly searching the same buildings and overall poor coordination. ${ }^{10}$ Following a repeat of these issues after the 1988 earthquake in Armenia, ${ }^{9}{ }^{11}$ attempts were made to harmonise international efforts, resulting in the 1991 formation of the International Search and Rescue Advisory Group (INSARAG), a global network of countries and organisations dealing with SAR related issues, operating under the UN's umbrella. ${ }^{12}$ Its main aim, and one of its key successes, has been establishing regularly reviewed, minimum international standards and guidelines for SAR. ${ }^{13}$ In 2002, a UN resolution was adopted endorsing INSARAG and establishing international consensus on the need for ISAR teams in postdisaster response. ${ }^{14}$ Since 2005, INSARAG has developed a classification system, INSARAG External 
Classification (IEC), designating teams as 'medium' or 'heavy' such that their capabilities can be established before deployment. ${ }^{15}$

Earthquakes have a significant impact on global health and development. While richer countries tend to experience higher costs due to damage to infrastructure of higher financial value, poorer countries have so far typically had higher mortality. ${ }^{16}$ Poverty affects the ability to recover; for example, an earning family member's death, destruction of property or livelihood interruption pushes people further into poverty and sets back overall development by years. ${ }^{17}$ This widens socioeconomic and other inequities, delaying progress in reducing health inequalities in affected populations. ${ }^{18}$

The populations threatened by earthquake disasters are increasing, largely due to population growth and infrastructure development without seismic safety measures. ${ }^{2}{ }^{19}$ Rapid construction of often multistorey buildings result in higher building density and occupancy, ${ }^{20}$ increasing potential earthquake disaster impacts. ${ }^{21}$ The reasons why some buildings are more likely to collapse than others are complex, but ultimately are often due to inadequate building standards or lack of enforcement of them, due to a failure to invest in standards and enforcement, alongside officials and the building industry ignoring any standards and protocols for financial gain. ${ }^{22}$ This inherent corruption further sets back overall development and proliferates the ongoing need for ISAR.

ISAR effectiveness has not been previously systematically reviewed, so this paper assesses ISAR response to earthquake disasters and its contribution to saving lives, by reviewing literature and other evidence from past earthquake ISAR response, using the number of people extricated from rubble alive as a direct measure of success. We also explore the evidence for local rescue after earthquakes, usually by relatives and neighbours, and costs involved in international response. Finally, we propose alternatives to postearthquake ISAR, focusing on pre-disaster risk reduction (DRR) and local capacity building.

\section{METHODS}

Data for this review were identified by searches of Web of Science, Scopus, Embase, Geobase, Georef and Google Scholar and then references from relevant articles, using the search terms "earthquake", "natural disaster", "natural hazard" and "search and rescue", "US\&R", "local/international response", "Immediate response".

Only articles published in English relating to earthquakes between 1985 and 2015 were included in the ISAR review, with earthquakes from any period included in the review of local response. See online supplemental appendix for full methods, including inclusion/exclusion criteria.

\section{Patient and public involvement}

It was not appropriate or possible to involve patients or the public in this type of study.

\section{Evidence for local rescue}

Table 1 presents a review of 13 studies covering assessment of local SAR response for specific earthquakes. These studies conclude that extrication of trapped individuals was performed by relatives, neighbours and local inhabitants in $60 \%-100 \%$ of cases described.

There are limitations to these data, such as its retrospective collection, sometimes with significant delays ${ }^{23}{ }^{24}$; use of hospital records which are noted to be incomplete, ${ }^{25}$ and will also fail to capture data from people who may be injured or die but never make it to hospital; anecdotal evidence where no systematic approach has been described for who was selected to take part ${ }^{26}$; and a lack of data from more recent events. These studies do not provide figures for the actual number of people trapped or rescued, or taking part in rescue operations. Despite these limitations, the reproducibility of findings in different events, along with expert consensus from field experience articulated in the citations, supports the conclusion of most postearthquake rescues being conducted by local people.

\section{ISAR live rescues}

Table 2 summarises ISAR contributions to lives saved in 14 earthquake disasters for 1985-2015. The highest number of live rescues by ISAR teams was 144 in Turkey, with Haiti second at 134 (range 132-136; see figure 1). Two post-Haiti agency reviews, ${ }^{27} 28$ also reported these as the highest figures.

When taking into account the estimated death toll for each event, only Pakistan has a lower value for 'live rescues as a percentage of deaths' than Haiti (aside from two events with no live rescues); however, the Turkey earthquake still has the highest figure for both 'live rescues' and 'live rescues as a percentage of deaths'. All earthquakes reviewed have an ISAR 'live rescues as a percentage of deaths' under $0.85 \%$ (see figure 2).

The lowest number of rescues occurred in Indonesia 2009 and Japan 2011, with no live rescues noted. ${ }^{29}{ }^{30}$ For the Japan earthquake, most deaths were reportedly a result of the subsequent tsunami, rather than earthquakeassociated building collapse, which was said to be minimal, ${ }^{31}$ although people trapped in any collapsed buildings might have been rescuable until they perished in the tsunami.

In the Armenia earthquake, only one source provided figures for the number of ISAR live rescues, 64, which it noted to be 'incomplete', while estimating that 15000 people overall had been rescued alive from collapsed buildings. ${ }^{32}$ A case control study of this event, ${ }^{33}$ found $0.9 \%$ of live rescues in the area surveyed, were saved by international teams. Applying $0.9 \%$ of rescues to the 15000 in Armenia would estimate 135 lives saved 


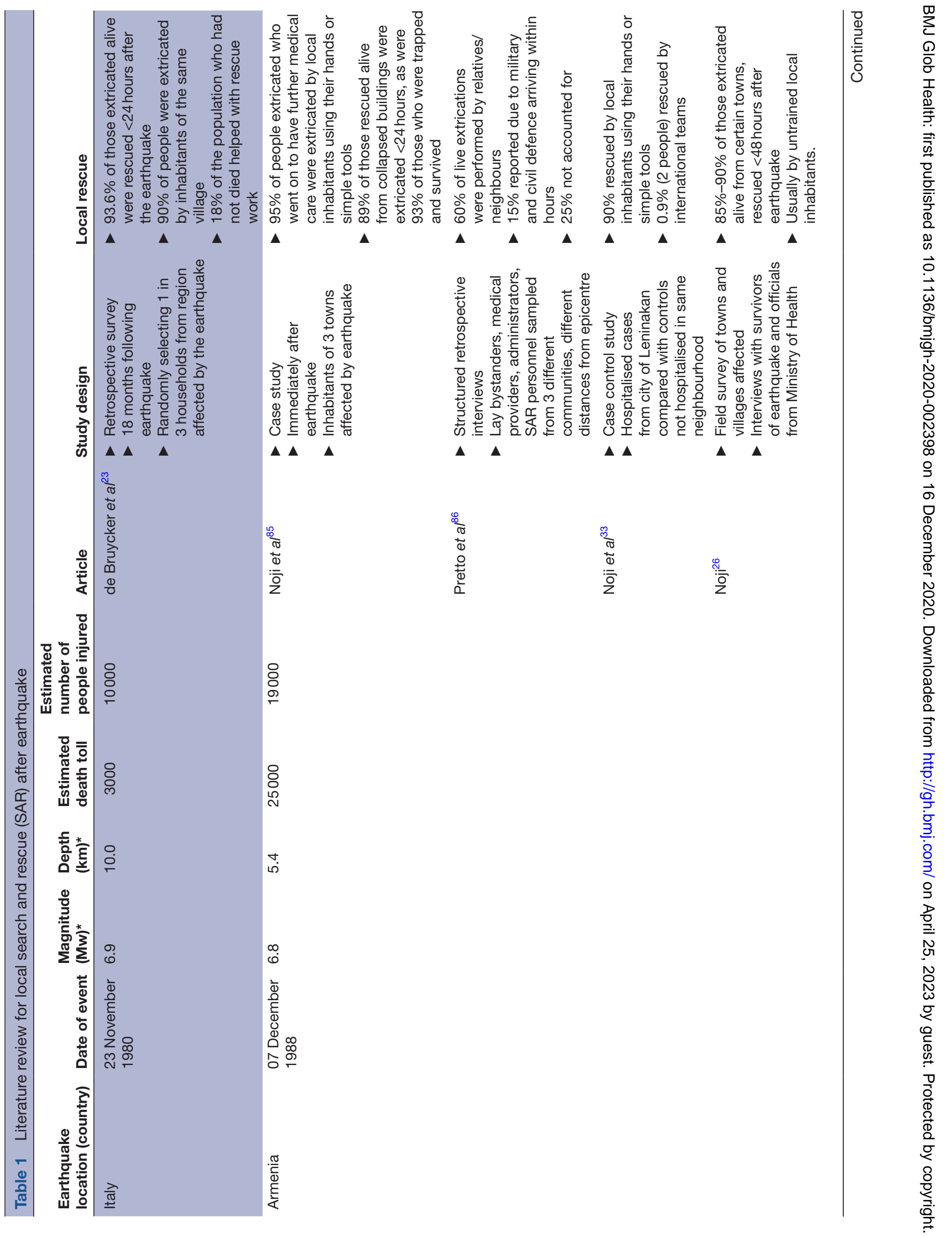




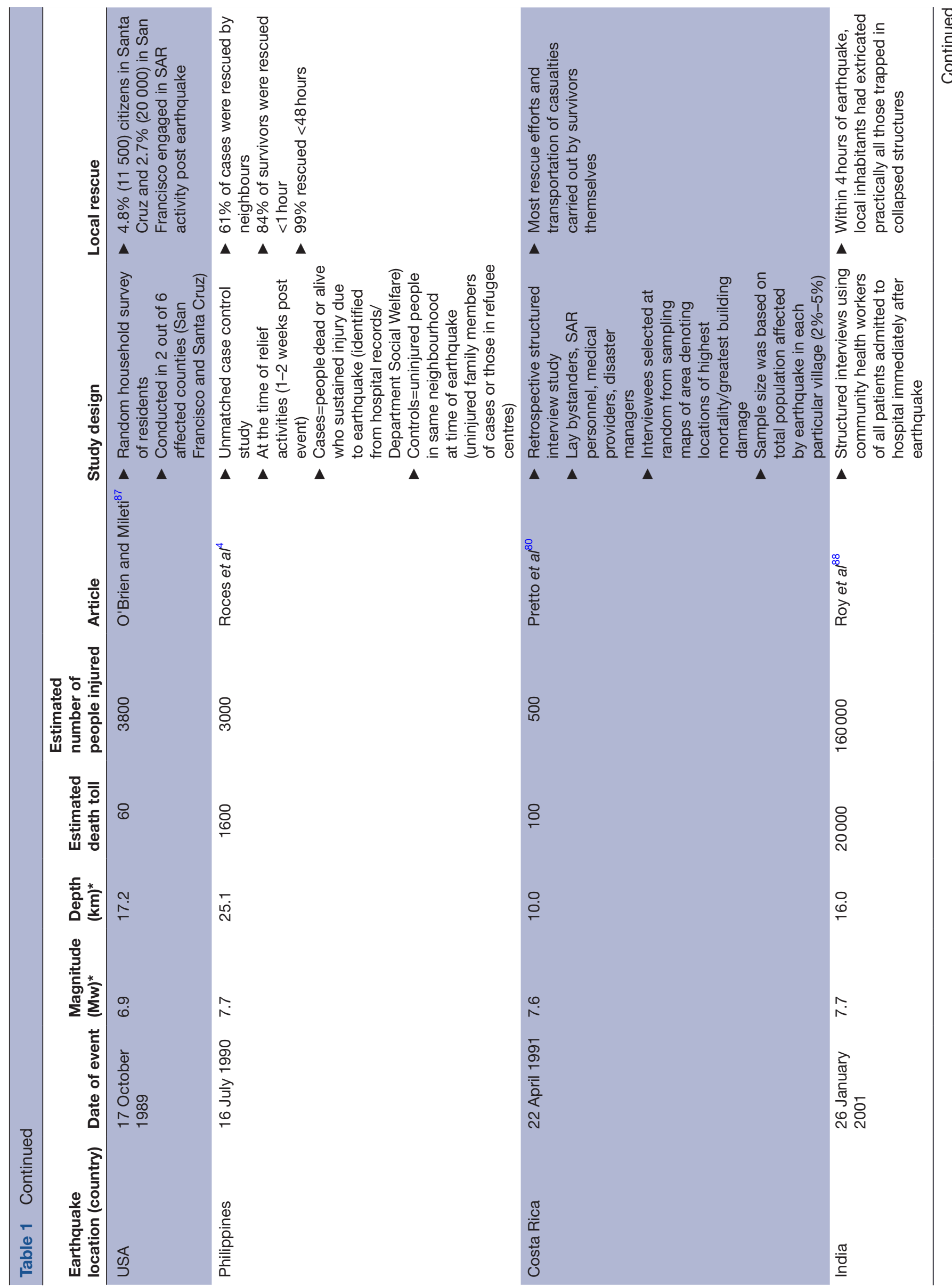




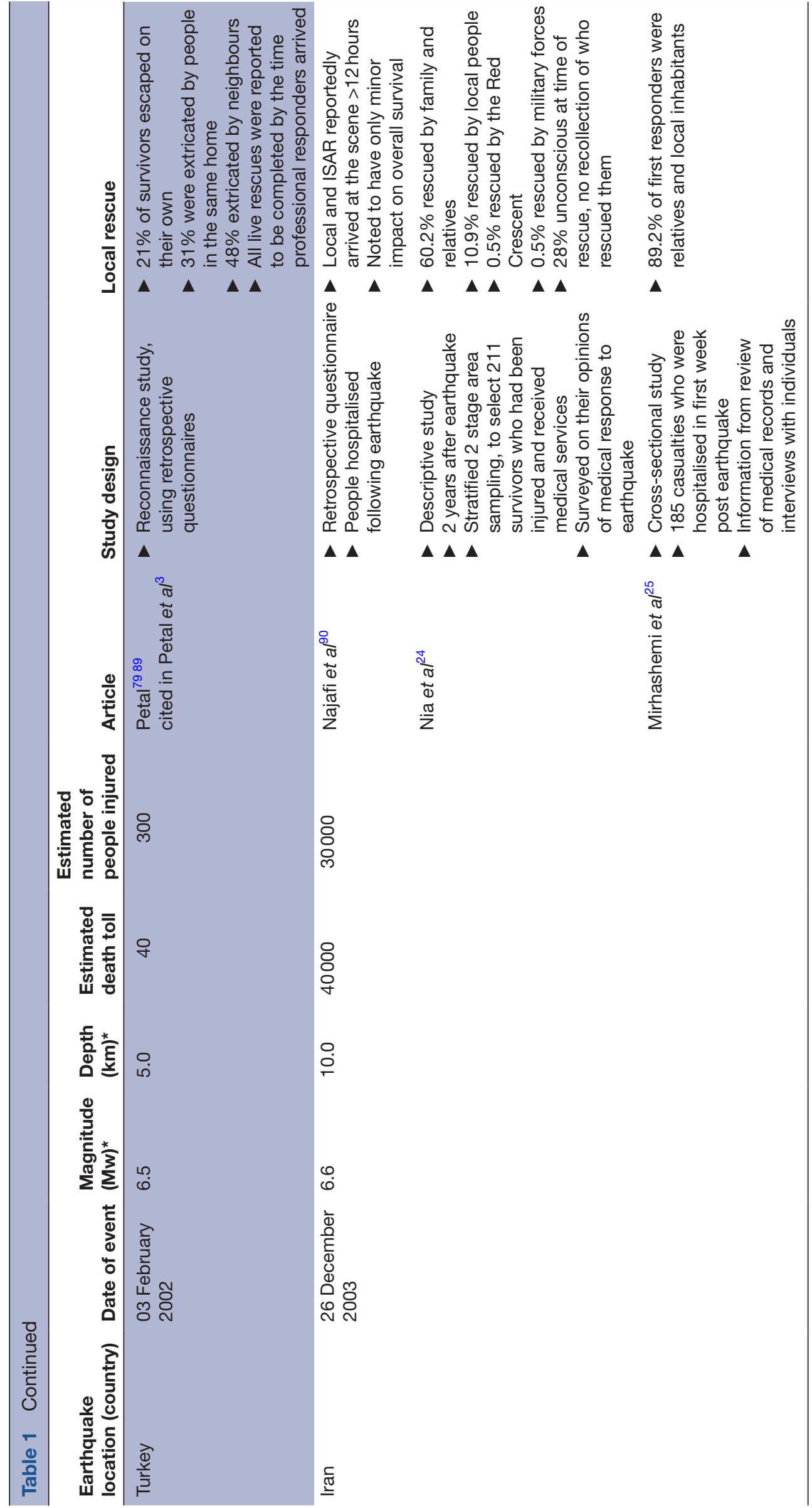

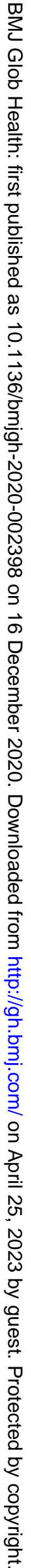




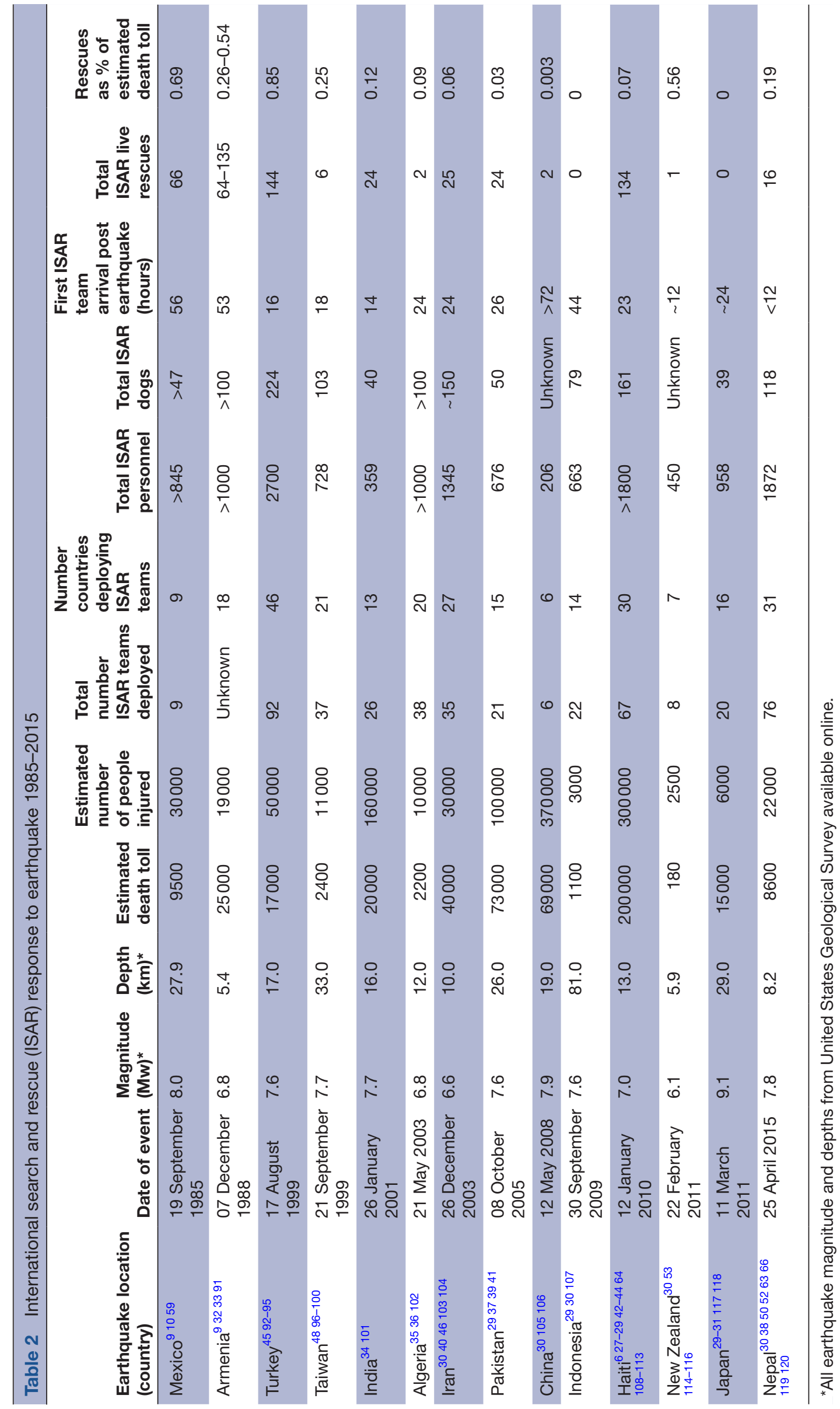


Total ISAR Live Rescues

160

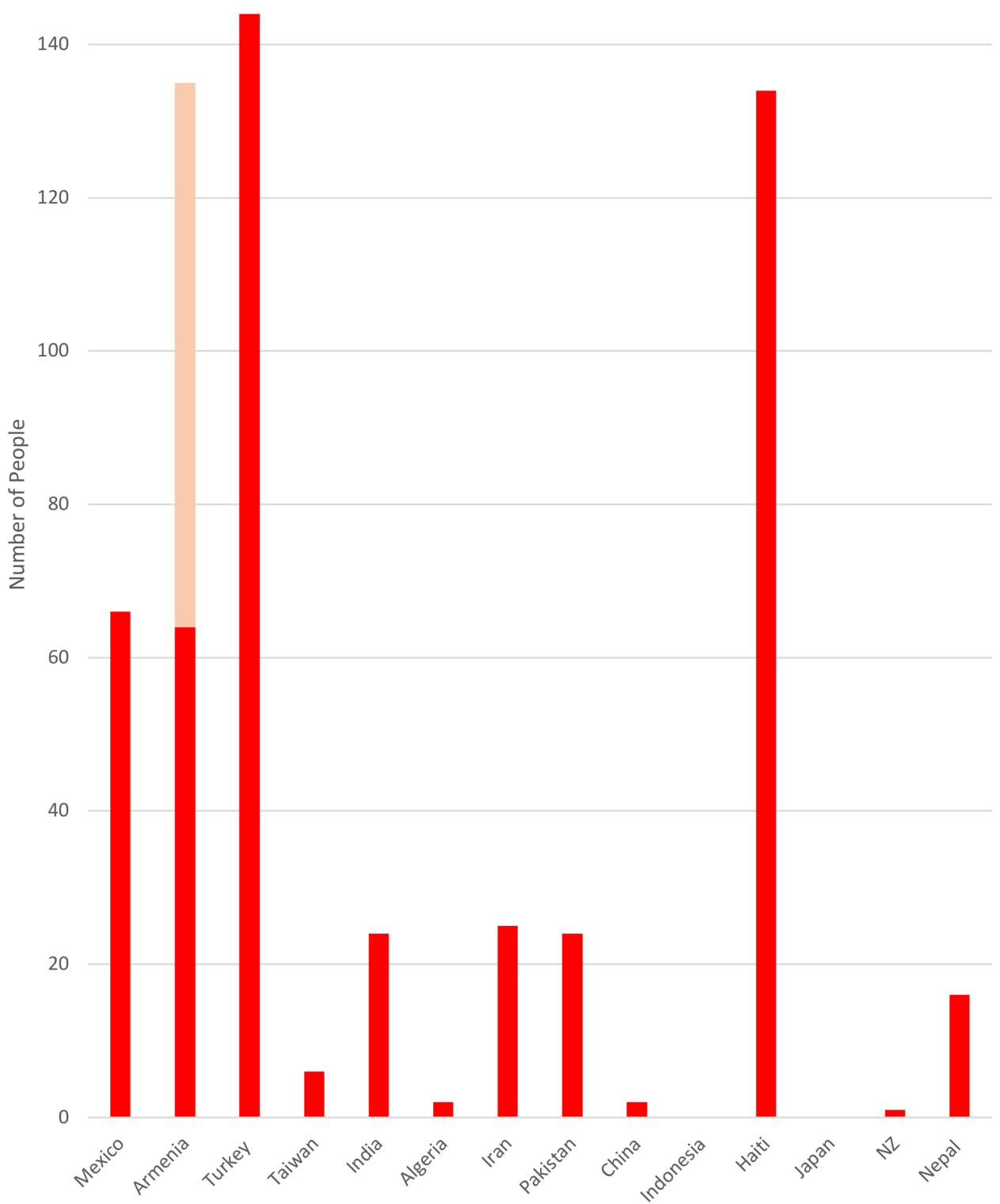

Figure 1 Number of live rescues made by ISAR teams for each earthquake.

by international teams, so it seems likely that the true number lies somewhere between 64 and 135 (shaded pink, figure 1).

The largest number of personnel responded to Turkey, Nepal and Haiti. There is no correlation between number of personnel/dogs and live rescues. Teams arrived in-country most quickly in Nepal and New Zealand ( $\leq 12$ hours), with the longest delay of $>72$ hours for the earthquake in China. No correlation is notable between the arrival time of the first ISAR team and the number of live rescues.

The majority of quoted figures for live rescues by ISAR teams come from the United Nations Office for the Coordination of Humanitarian Affairs (OCHA) who are tasked with onsite coordination of the ISAR response. Numbers are provided in their situation update reports and via the virtual On-site Operations Coordination Centre, vOSOCC, available online. ${ }^{84-38}$ Even where numbers are quoted in the literature, they are usually derived from OCHA reports. ${ }^{29} 303239$

Many reports in the grey literature do not reference where data for live rescues come from, but often figures will match OCHA reports. ${ }^{28}{ }^{40-44}$ Many OCHA reports, describe the number of attending ISAR teams and personnel/dogs only, without mention of live rescues. ${ }^{45}{ }^{46}$ Many of the reports from individual agencies, such as United States Agency for International Development (USAID), detailing their own teams' rescues, 


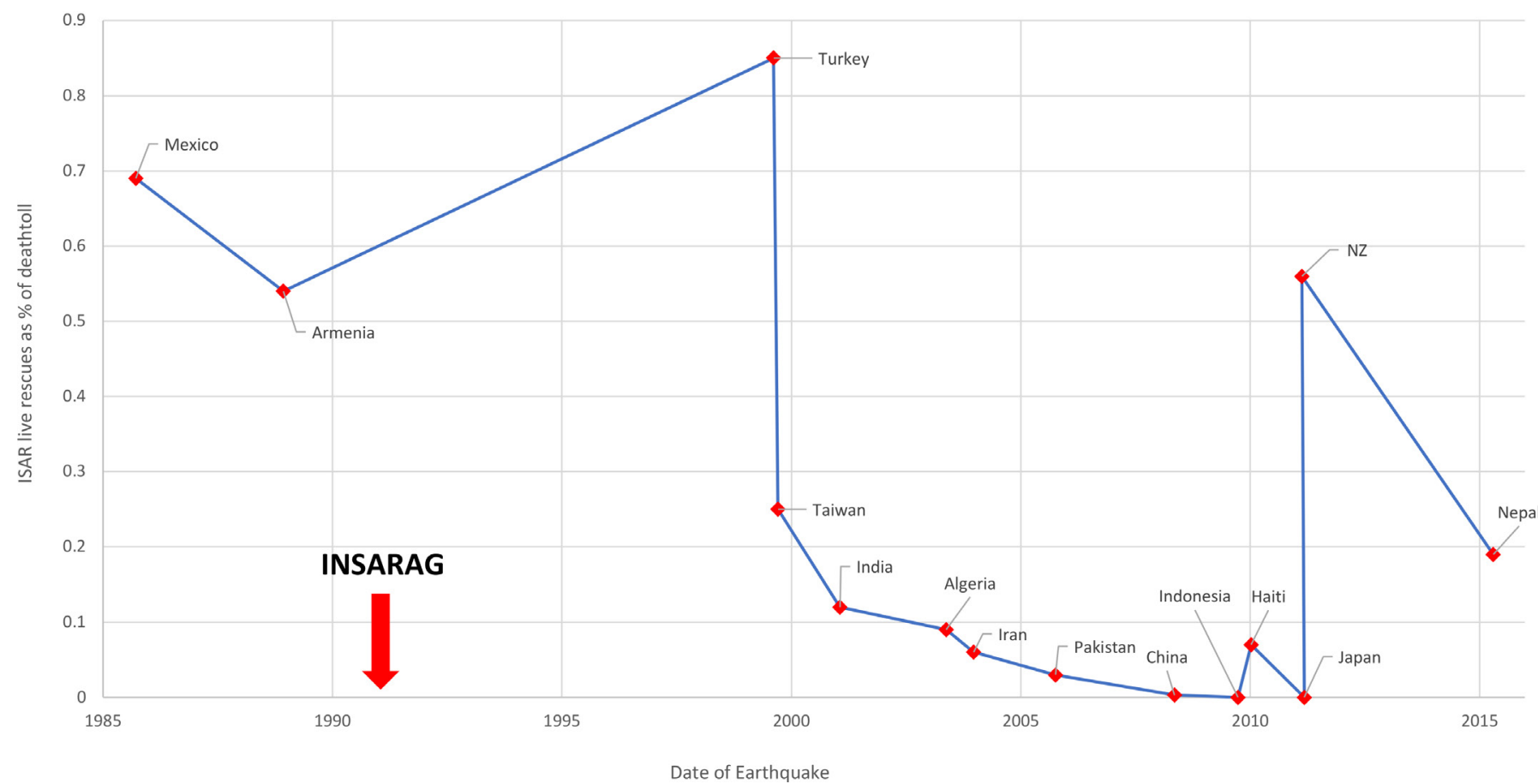

Figure 2 ISAR live rescues as a percentage of death toll for each earthquake event over 30-year period from 1985-2015 (Maximum possible live rescues as \% of death toll figure used for Armenia, range 0.26-0.54).

support the overall findings for number of rescues in OCHA reports, corroborating the magnitude of the numbers described. ${ }^{478}$ Overall, between 1985 and 2015, ISAR teams reportedly made 508-579 live rescues.

\section{Costs of UK and US ISAR response 2010-2015}

Table 3 presents the costs of UK and US ISAR teams in response to three earthquakes during a 5-year period, as both UK and US teams deployed to these events, and data were available for both countries to allow comparison. UK and US costs were chosen as reports are in English, USAID publishes budget breakdowns with situation updates and UK government departments are subject to Freedom of Information (FOI) requests, where information is not publicly available.

The total UKISAR spending on these events was US\$3 173 300, with US\$793 325/life saved. Total USISAR spending was US\$44 960 908, with US\$936 686/life saved. Combined spending/life saved was US $\$ 925658$. An FOI request was made to the UK's Department for International Development (DFID) to provide costs for all UKISAR deployments since 1985, but this was declined citing the excessive cost to DFID of providing this information.

\section{DISCUSSION}

\section{Overview of ISAR success}

There is limited peer reviewed literature specifically assessing ISAR teams' response to earthquake disasters (see table 2). The data that are available indicate that these teams save relatively few lives, compared with the numbers affected by these earthquakes, or likely to have been saved by local inhabitants.

The data on ISAR rescues have not been systematically collected or widely reported. While most ISAR teams are government sponsored, any rescues by private teams or those not supported by governments, are unlikely to have been recorded, as they usually work outside of the OCHA coordination system. ${ }^{32}$ In some cases, live rescues will have been counted where individuals later died, ${ }^{28} 49$ decreasing the overall success of the intervention. Where numbers have been publicly stated, particularly in Haiti and Nepal, with more references in the literature than previous earthquakes, there are no findings of counter claims or critiques to suggest these figures are disputable. Overall, therefore, despite the limitations of the data, it appears to be a reasonable representation of the contribution of ISAR to number of lives saved.

Specific details on the circumstances of live rescues made by these teams are lacking. ${ }^{314}$ This type of data should be straightforward to collect, given the small numbers of rescues involved. Recording the type of equipment used, medical condition of the individual and specific timings of rescue would provide useful data to inform future practice. Could the extraction have been done by less skilled rescuers? Was specialised equipment required? What were the immediate medical needs and first aid provided after extrication? Were any rescuers injured or killed during the operation? INSARAG have developed a "Victim Extrication Form', to document some of this information and has advocated use of post mission reporting, but not all 


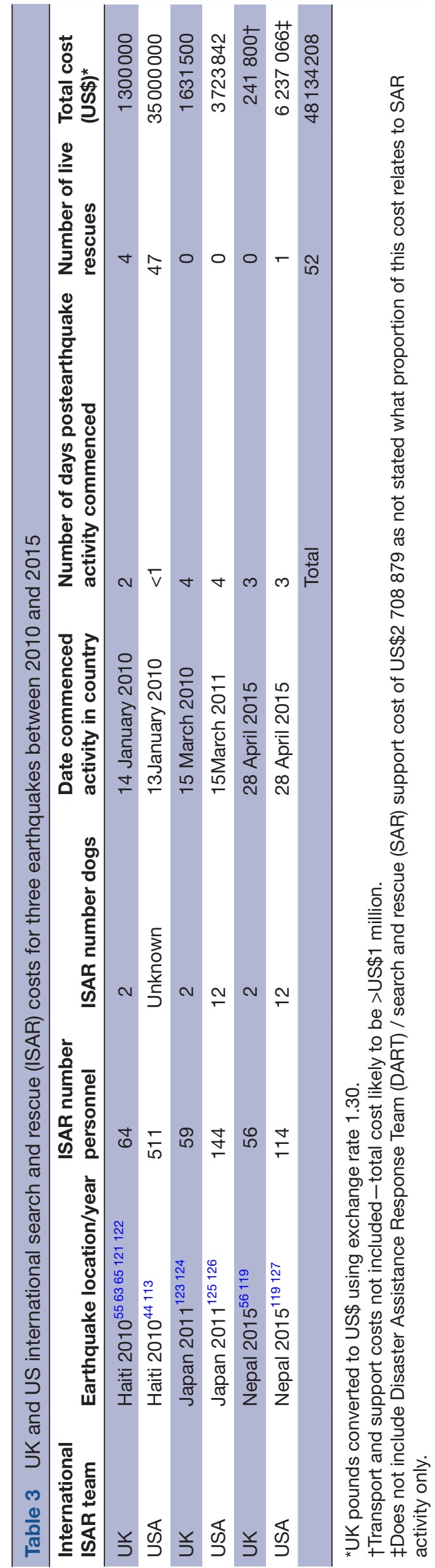

teams are completing these forms, or reporting their activity. ${ }^{50}$

Over the years, since the formation of INSARAGproducing best practice guidelines, classifying teams and improving coordination via OCHA-success, measured by live rescues, of ISAR teams might be expected to improve. The data collected, however, do not show a pattern of improvements in lives saved over time (see figure 2). While INSARAG and the international community should be applauded for the improvements they have made to best practice and coordination, this has not had demonstrable effects on the lives these teams save. ${ }^{51}$ This is not down to the lack of skill or efforts of the ISAR teams themselves, who work tirelessly in exceptionally difficult conditions trying to save lives. ${ }^{29}$

The likely reason is that the main factor determining lives saved is the time taken for ISAR teams to arrive on site and become operational. Despite organisational improvements in time taken to deploy, it will always take at least some hours to assemble teams and find suitable transport. ${ }^{52}$ This added to the time it takes to fly to often distant countries becomes a fixed rate-limiting step to operations, until perhaps suborbital travel becomes a commercial reality. Since the evidence points to most rescues being performed locally in the immediate aftermath, these delays result in few lives being saveable. Even in earthquakes where some teams have arrived within 12 hours, the numbers of rescues has remained small, further supporting that most rescues have either already taken place or those trapped have already died.

In their review of the Nepal earthquake ISAR response, Okita \& Shaw, concluded that to improve the efficiency of response, IEC-classified teams from neighbouring countries should be prioritised, ahead of non-classified teams. ${ }^{30}$ However, in the Nepal earthquake, the first team to arrive was India's non-classified SAR team, who made the most rescues (11) of any of the teams, with only four of the remaining five rescues made by classified teams. Had Nepal declined India's non-classified team and waited longer for a classified team's arrival, would those 11 people have been extricated alive? The OCHA independent review report on the Nepal earthquake, concluded that "focus should be given on capacity building...in disaster prone-countries more than on classifying international...teams". ${ }^{50}$

\section{Costs of ISAR}

Multiple authors report the costliness of ISAR without providing actual costs. ${ }^{30} 5153$ Alexander estimates the overall cost of ISAR at around US $\$ 1$ million per life saved. ${ }^{6}$ No explanation is given for how this conclusion is reached; however, it would largely be supported by the costs presented in table 3 and the frequency of rescues.

An average 'heavy' ISAR team deployment has been estimated to cost around US $\$ 900000,{ }^{29}$ and is usually made up of 50-70 people with about 30 tons of equipment. ${ }^{11}$ The UK team reasonably represents an average 
'heavy' team and quoted costs (table 3) are broadly in line with these estimates.

It is difficult to estimate how many teams are deploying at what capacity and therefore how much variation in cost this may introduce. For example, only 18 out of 76 teams in Nepal were IEC classified, ${ }^{30}$ and only 8 out of 67 in Haiti. ${ }^{28}$ If we were to use the average deployment cost of US $\$ 1$ million/average team of 50 personnel, assuming some would be more and some less costly, the overall estimated total cost of ISAR for the 14 events described, would be around US\$300 million. Estimates based on US $\$ 1$ million/life saved would be $\$$ US500-600 million. While it is tempting to try to estimate an overall cost of ISAR, there is a risk of significantly underestimating or overestimating these costs, and therefore such estimates have not been included in table 2 .

Average costs do not take into account some much more costly deployments, such as the US Haiti response. In Haiti, the US deployed four extra domestic SAR teams, in addition to their usual two international teams, costing US\$26 million. USAID's independent review of this response ${ }^{44}$ concluded that these extra teams had 'little impact'. No critique of the additional US $\$ 9$ million spent on its IEC classified teams was offered.

It should be noted that there are costs associated with maintaining the ability to deploy, for example, for the period 2015-2018, it cost DFID $£ 530000$ to cover stand-by costs of the UKISAR team. ${ }^{54}$ It is unclear how much of these costs encompass setting up, maintaining and training for the teams in the absence of specific disasters.

DFID declining to provide information, following the FOI request, ${ }^{55}$ on UKISAR response in the last 30 years, implies that these data were not being routinely recorded or reported in an accessible way, although more recent events do have some data available online through their development tracker. SAR costs, however, are often not itemised separately from other aid. The cost for UKISAR response for Nepal was obtained by a subsequent, focused FOI request to DFID. Their response of $£ 186000$ (US $\$ 241800)^{56}$ was later acknowledged not to include transport or support costs and only represents the costs paid directly to the UK Fire and Rescue Service. As transport usually makes up the bulk of the expense, the true cost is likely similar to deployments to Japan and Haiti, which were $>$ US $\$ 1$ million, therefore making the overall costs/life saved much closer to US $\$ 1$ million.

A 2011 review of the UK government's response to humanitarian emergencies ${ }^{55}$ concluded that UKISAR was expensive and often arrived too late. It cited the example of UKISAR costing over $£ 250000$ per life saved in Haiti, 100 times more than responding surgical teams, at $£ 2500$ per life saved. The comparison of a feeding programme in Niger which cost just over $£ 100$ per child saved was given. It suggested the UK should be 'smart' about where it deploys and develop 'niche capabilities' in nuclear, chemical and biological SAR. This does not appear to have impacted the decision to deploy UKISAR to Nepal in 2015.

Rescuer deaths were only found reported following the 1985 Mexico City earthquake, with 100-135 rescuers reportedly killed while attempting rescue.$^{57} 58$ No detail is given as to whether these were trained, local or international team members; however, the number of deaths is significant, particularly when compared with the 66 rescues made by international teams, ${ }^{59}$ and the estimated 600 rescues made overall. ${ }^{57}$ Despite this being the only specific mention of rescuer deaths found, the dangers of working in these conditions is high. ${ }^{49}$ All ISAR team members make an informed choice to work in these conditions, but given the low numbers of lives saved by most teams, ethical consideration should be given to sending teams into dangerous circumstances with low chance of successful outcome and high emotional demand.$^{60}$ Various studies have reported increased levels of post-traumatic stress disorder in first responders and SAR workers. ${ }^{61}$

ISAR response occupies the attention and resources of critical personnel and equipment ${ }^{62}$ and despite many teams' self-sufficiency, often uses local resources, such as communications and transport, which can be limited post disaster. Following earthquakes, critical infrastructure such as airports is often damaged. The volume of aid and personnel that can be successfully transported to an earthquake-hit area is therefore constrained. ${ }^{29}{ }^{63}$ Flying in ISAR teams and resources takes up a proportion of the initial capacity of other aid such as healthcare, sanitation and shelter. ${ }^{29} 64$

\section{Other reasons for ISAR response}

During operations, ISAR teams perform other tasks, such as first aid and body recovery. Responsibility for most body recovery is left to local authorities, ${ }^{50}{ }^{54}$ with other duties, such as aid distribution, engaged in if SAR is not feasible. ${ }^{65}$ Some team members perform important building and structural assessments ${ }^{27}{ }^{62}$; however, this usually involves a few team members (structural engineers) without need for heavy equipment. As ISAR teams are often the first international personnel arriving in country, they can provide initial assessments and information on the scale of the disaster and priorities, disseminated to the international community via the vOSOCC. ${ }^{27}$

Arrival of ISAR teams has been reported to increase morale and take pressure off fatigued local teams. ${ }^{66}$ Many teams, like the UK's, come from countries unlikely to experience major earthquake disasters. Responding to international events has been seen as a valuable opportunity for training and experiencing 'real disaster'. ${ }^{545}$

Some advocates of ISAR cite its value to international diplomacy as an important byproduct. ${ }^{53} 66$ Despite potential short-term benefits, to date, there have been no reported examples of new postdisaster diplomatic initiatives achieving conflict reduction. ${ }^{67}$ DFID notes that UKISAR teams "wear the DFID UK AID logo on their uniforms and may give press interviews' ${ }^{54}$ which 
generates public support and donations to UK aid agencies but also raises the profile and appreciation of DFID's work, regardless of whether the action is ultimately helpful. ${ }^{29}$

The media's role in ISAR response is important. ISAR teams receive a lot of media attention, ${ }^{52}$ often when there are more pressing needs such as water and shelter. By generating public interest, media presentation of these disasters can put pressure on politicians to send resources. ${ }^{115066}$ Fear of criticism in the media has been a cited reason for visible ISAR response, ${ }^{30}{ }^{50}$ such as requesting ISAR when it is felt unnecessary, ${ }^{68}$ and deploying to avoid criticism, as experienced by the Norwegian government when they declined to deploy their ISAR assets to Haiti. ${ }^{43}$ Public expectation of 'international rescues' and the exciting images they generate should be countered with real stories of survival and rescue, which could be made as compelling.

\section{Alternatives to postearthquake disaster ISAR}

How do we decide whether an intervention is successful? Is saving around 500 lives over 30 years 'enough'? The debate on how best to fund overseas aid is complex. ${ }^{11}$ From a utilitarian perspective, some would argue we should fund only the projects that save the most lives, ${ }^{69}$ so perhaps feeding programmes in Niger, rather than earthquake response in Haiti. ${ }^{55}$ Burden of disease develop, apply, and critique more complex metrics such as qualityadjusted life years and disability-adjusted life years, calculations which have not fully entered into ISAR discussions.

The UN High Commissioner for Human Rights has advocated a human-rights based approach to disaster response, ${ }^{70}$ recognising those affected by disaster as 'rights holders with entitlements' and the need for collaborative assistance, rather than making those affected the passive recipients of aid. ${ }^{71}$ This recognises the role of the individual, not just in having the right to assistance, but also in having the right to input into what that assistance should be. ${ }^{72}$ Engaging in this type of collaborative effort as a disaster unfolds can be challenging, and so preparing for disaster becomes an even more important priority. Medical research again provides insights, in terms of whether or not health as a fundamental human right includes (or should include) the right to survive in disasters while also potentially modelling collaborative aid for disaster rescue-especially predisaster-on collaborative and participatory healthcare and illness prevention.

'Mitigation and preparedness involve both reducing the need for response and increasing the ability to respond'. ${ }^{3}$ The main goal of the UN's Sendai Framework for DRR is to "prevent and reduce hazard exposure and vulnerability to disaster, increase preparedness for response and recovery, and thus strengthen resilience'. ${ }^{73}$ Just as preventative medicine allows an opportunity to intervene to avoid rather than treat disease, DRR aims to prevent a hazard from killing, injuring and affecting the livelihoods of those impacted, ultimately attempting to make these events 'the disasters that did not happen'. 74 This potentially avoids or mitigates a knock-on detrimental effect to population health. ${ }^{20}$

Given that building collapse is the main direct cause of earthquake deaths, ${ }^{6}$ improving building codes and their implementation and enforcement, ${ }^{75}$ as has been successful in countries like Japan, ${ }^{16}$ or retrofitting older buildings, would significantly reduce deaths and injuries from earthquake and the need for SAR. ${ }^{76}$ Apart from the higher costs involved in seismic construction, corruption in all countries continues to be a further barrier. In addition to its direct impact on potential for building collapse, corruption affects the overall development of affected places, impacting areas such as healthcare and education. Tackling corruption requires a complex multifaceted approach, but overall political will has to be forthcoming to achieve progress. While improving building construction standards in a country such as Haiti, for example, would have obvious benefits, it is not an achievable objective, at least in the shorter term. ${ }^{19}$

Studies have estimated seismic construction would add $5 \%-15 \%$ to the cost of building a school, protecting children from death, injury and the costs of interrupted education. ${ }^{77}$ A 2012 study estimated the cost of retrofitting all schools in the 35 most exposed countries reviewed, would be around US $\$ 300$ billion, saving 250000 lives over 50 years. ${ }^{78}$ Whether the benefit-cost ratio is positive or not depends on the monetary value placed on a human life. Several studies have suggested resources would be better invested in predisaster local capacity building and preparedness than postdisaster response. ${ }^{6} 1679$ INSARAG has long advocated local capacity building, with the eventual goal to eliminate the need for ISAR. ${ }^{9}$

The shortfall in the ability of even richer countries to maintain large enough professional SAR response has long been noted. ${ }^{52} 80$ Since 1993, the Federal Emergency Management Agency in the USA has been supporting communities with programmes to train local volunteers in disaster preparedness, for example, Community Emergency Response Teams (CERT). ${ }^{81}$ The CERT premise has been applied outside the USA; for instance, 6000 volunteers were trained in the Marmara region of Turkey, the site of the devastating 1999 earthquake. ${ }^{3}$ While the literature supports the 'incredible potential' of CERT, ${ }^{82}$ there are to date no studies evaluating such interventions in the postearthquake period. Further research is also needed into key skills and information that should be taught, how best to relay this knowledge, who best to receive it and how long it may be retained. ${ }^{76}$

While specific costs of community SAR training are not available in the literature, it would likely be comparable to low-cost programmes providing community first aid training. In one of the few examples evaluating the benefits of including first aid training, the Red Cross/Red Crescent estimated a benefit-cost ratio of 19 for their DRR activities in Nepal. ${ }^{83}$

INSARAG has proven its value in sharing international experience and producing best practice guidance and 
already has a programme of local capacity building and assessments for countries requesting reviews of existing systems. As of 2015, only five such assessments had been conducted.$^{50}$ Governments and donors should be encouraged to fund their specialist ISAR teams to take part in this exchange of skills and training, predisaster rather than postdisaster.

\section{Limitations}

Excluding non-English studies may neglect potentially useful insights; for example, from a title search nonEnglish papers are relevant. ${ }^{84}$ Reported costs do not account for inflation and currency fluctuations. Data taken from the grey literature have to be interpreted within the context in which it is being reported, in that there might be vested interests in presenting data in a positive way, to avoid criticism or withdrawal of funding, or because the outcome in terms of lives saved does not represent the efforts expended in attempting rescues.

\section{CONCLUSIONS}

ISAR has a limited capacity to save lives postearthquake, largely due to the time taken for teams to become operational, so that most rescues have seemingly already been performed by local people immediately afterwards. Since the $1980 \mathrm{~s}$, the international community increasingly deployed SAR teams despite evidence already existing that it was unlikely to have a significant impact, with the last 30 years of earthquake disasters supporting this conclusion.

Some may argue that the individual lives saved by this response justify the deployment costs. Individually, any life saved should be considered a success. From a human rights-based perspective, we must consider whether we are fulfilling our obligations to all those affected. While evidence for interventions in disaster settings can be difficult to obtain, where evidence does exist, the international community has a responsibility to use it to design better responses. Responding ISAR teams can assist this process by collecting and sharing more detailed data on the lives they do save.

As capacity to save lives after an earthquake is limited, pre-DRR is paramount for reducing disaster morbidity and mortality. It will be vital to find ways to engage the media in telling how most people survive or die in these events, and in helping to hold politicians and policymakers to account for the choices made in spending money to prepare for or react to disaster, and combat corruption. Further study on the effectiveness of community preparedness programmes and local capacity building will also be required.

This review should not be seen by policy makers as an excuse to withdraw funding from ISAR. SAR does save lives, but for it to fully realise its potential, local capacity in at-risk communities needs to be built, in part by using the skills and hard work of ISAR teams before rather than after disaster strikes, and ultimately by empowering communities to rescue themselves.

Contributors AR performed the literature search and data analysis, and wrote the first full draft of the manuscript. IK provided substantial critical review of the manuscript, as well as further insights, material, and editing. AR led the study design and framing, with support and input from IK.

Funding The authors have not declared a specific grant for this research from any funding agency in the public, commercial or not-for-profit sectors.

Competing interests None declared.

Patient consent for publication Not required.

Provenance and peer review Not commissioned; externally peer reviewed.

Data availability statement Data sharing not applicable as no datasets generated and/or analysed for this study.

Supplemental material This content has been supplied by the author(s). It has not been vetted by BMJ Publishing Group Limited (BMJ) and may not have been peer-reviewed. Any opinions or recommendations discussed are solely those of the author(s) and are not endorsed by BMJ. BMJ disclaims all liability and responsibility arising from any reliance placed on the content. Where the content includes any translated material, BMJ does not warrant the accuracy and reliability of the translations (including but not limited to local regulations, clinical guidelines, terminology, drug names and drug dosages), and is not responsible for any error and/or omissions arising from translation and adaptation or otherwise.

Open access This is an open access article distributed in accordance with the Creative Commons Attribution Non Commercial (CC BY-NC 4.0) license, which permits others to distribute, remix, adapt, build upon this work non-commercially, and license their derivative works on different terms, provided the original work is properly cited, appropriate credit is given, any changes made indicated, and the use is non-commercial. See: http://creativecommons.org/licenses/by-nc/4.0/.

\section{ORCID iD}

Anna Rom http://orcid.org/0000-0002-6014-7069

\section{REFERENCES}

1 Wallemacq P. Economic losses, poverty \& disasters: 1998-2017: Centre for Research on the Epidemiology of Disasters, CRED. Available: https://www.unisdr.org/files/61119_credeconomiclosses. pdf [Accessed 29 Dec 2019].

2 Bartels SA, VanRooyen MJ. Medical complications associated with earthquakes. The Lancet 2012;379:748-57.

3 Petal MA, Celep U, TüZün C, et al. Teaching structural hazards awareness for preparedness and community response. Bull Earthquake Eng 2004;2:155-71.

4 Roces MC, White ME, Dayrit MM, et al. Risk factors for injuries due to the 1990 earthquake in Luzon, Philippines. Bull World Health Organ 1992;70:509.

5 Ashkenazi I, Isakovich B, Kluger Y, et al. Prehospital management of earthquake casualties buried under rubble. Prehosp Disaster Med 2005;20:122-33.

6 Alexander D. What can we do about earthquakes? towards a systematic approach to seismic risk mitigation. Bulletin of the New Zealand Society for Earthquake Engineering 2012;45:49-60.

7 Leeds A. El-Asnam, Algeria earthquake October 10, 1980: a reconnaissance and engineering report, Washington DC: National Academies 1983.

8 El-Tawil S, Aguirre B. Search and rescue in collapsed structures: engineering and social science aspects. Disasters 2010;34:1084-101.

9 Bookmiller K. The International Law of 96 Hours: Urban Search and Rescue Teams and the Current State of International Disaster Response Law. In: Caron MK D, Telesetsky A, eds. The international law of disaster relief. Cambridge: Cambridge University Press, 2014: 111-36.

10 Comfort LK. International disaster assistance in the Mexico City earthquake. FMHI publications 1986;3.

11 Katoch A. The responders' cauldron: The uniqueness of international disaster response. Journal of International Affairs 2006:153-72.

12 INSARAG. INSARAG background. Available: https://www.insarag. org/about/background [Accessed 29 Dec 2019]. 
13 Tatham P, Spens K. Cracking the humanitarian logistic coordination challenge: lessons from the urban search and rescue community. Disasters 2016;40:246-61.

14 UN. UN Resolution 57/150. Strengthening the effectiveness and coordination of international urban search and rescue assistance [UN resolution]. Available: https://www.insarag.org/images/stories/ GA_Res_57-150_English.pdf [Accessed 29 Dec 2019].

15 INSARAG. INSARAG external classification (IEC). Available: https:// www.insarag.org/iec [Accessed 29 Dec 2019].

16 Booth E. Dealing with earthquakes: the practice of seismic engineering 'as if people mattered'. Bull Earthq Eng 2018;16:1661-724.

17 Green GB, Modi S, Lunney K, et al. Generic evaluation methods for disaster drills in developing countries. Ann Emerg Med 2003;41:689-99.

18 Marmot M, Allen JJ. Social determinants of health equity: American Public Health Association 2014

19 Doocy S, Daniels A, Packer C, et al. The human impact of earthquakes: a historical review of events 1980-2009 and systematic literature review. PLoS Curr 2013;5. doi:10.1371/ currents.dis.67bd14fe457f1db0b5433a8ee20fb833. [Epub ahead of print: 16 Apr 2013]

20 WHO. Earthquakes - Technical Hazard Sheet - Natural Disaster Profile. Available: https://www.who.int/hac/techguidance/ems/ earthquakes/en/ [Accessed 29 Dec 2019].

21 Statheropoulos M, Agapiou A, Pallis GC, et al. Factors that affect rescue time in urban search and rescue (USAR) operations. Nat Hazards 2015;75:57-69.

22 Lewis J. Housing construction in earthquake-prone places: perspectives, priorities and projections for development. Aust $J$ Emerg Manag 2003;18:35.

23 de Bruycker M, Greco D, Annino I, et al. The 1980 earthquake in southern Italy: rescue of trapped victims and mortality. Bull World Health Organ 1983;61:1021.

24 Nia MS, Nafissi N, Moharamzad Y. Survey of Bam earthquake survivors' opinions on medical and health systems services. Prehosp Disaster Med 2008;23:263-8.

25 Mirhashemi S, Ghanjal A, Mohebbi HA, et al. The 2003 Bam earthquake: overview of first aid and transport of victims. Prehosp Disaster Med 2007;22:513-6.

26 Noji EK. Medical and healthcare aspects. Earthquake Spectra 1989;5:161-9.

27 INSARAG. Haiti Earthquake Response 2010 - An After-Action Review of Response. Available: https://www.insarag.org/images/ stories/Documents/Haiti_AAR_Meeting/Printed_Haiti_Book_Low_ Definition Version.pdf [Accessed 29 Dec 2019].

$28 \mathrm{CdV}$ deG, Grünewald F, Sarmiento JP. Health responses to the earthquake in Haiti January 2010: lessons to be learned for the next massive sudden-onset disaster: Pan American Health Organization (PAHO). Available: http://new.paho.org/disasters/ dmdocuments/HealthResponseHaitiEarthq.pdf [Accessed 29 Dec 2019].

29 Peleg K, Kellermann AL. Medical relief after earthquakes: it's time for a new paradigm. Ann Emerg Med 2012;59:188-90.

30 Okita Y, Shaw R. Effects of the classification system in internationa SAR: the case of the 2015 Nepal earthquake. Disaster Prev Manag 2019;28:359-70.

31 Koresawa A, Fire and Disaster Management Agency (FDMA), Ministry of Internal Affairs and Communication, 2-1-2 Kasumigaseki, Chiyoda-ku, Tokyo 100-8927, Japan. EvidenceBased analysis of search and rescue operations following the great East Japan earthquake. J Disaster Res 2013;8:746-55.

32 Krimgold F. Search and rescue. Earthquake Spectra 1989;5:136-49.

33 Noji EK, Armenian HK, Oganessian A. Issues of rescue and medical care following the 1988 Armenian earthquake. Int $J$ Epidemiol 1993;22:1070-6.

$34 \mathrm{OCHA}$. United nations disaster assessment and co-ordination (UNDAC) team Bhuj final report. Available: https://reliefweb. int/report/india/united-nations-disaster-assessment-and-coordination-undac-team-bhuj-final-report [Accessed 29 Dec 2019].

35 vOSOCC. Algeria 2003 vOSOCC Discussion - International USAR Response Comments. Available: https://vosocc.unocha.org/ VODiscussions.aspx\#_top [Accessed $28 \mathrm{Jul} 2019]$.

36 vOSOCC. Algeria 2003 vOSOCC Discussion - Situtation Comments. Available: https://vosocc.unocha.org/VODiscussions. aspx\#_top [Accessed $28 \mathrm{Jul} 2019]$

37 vOSOCC. Pakistan/India 2005 vOSOCC Discussion - International USAR Response Comments. Available: https://vosocc.unocha.org/ VODiscussions.aspx\#_top [Accessed 28 Jul 2019]

38 OCHA. Nepal: live rescues made by international urban search and rescue teams (4 may 2015). Available: https://reliefweb.int/map/ nepal/nepal-live-rescues-made-international-urban-search-andrescue-teams-4-may-2015 [Accessed 29 Dec 2019]

39 Smith P. Earthquake relief: shifting attention? World Conference on Humanitarian Studies, Groningen, the Netherlands 2009;8.

40 IFRC. Operations review of the red cross red crescent movement response to the earthquake in Bam, Iran. Available: https://www. ifrc.org/docs/evaluations/eval04/Bam-operations-review.pdf [Accessed 29 Dec 2019].

41 DFID. Pakistan earthquake: what the UK did and what we're doing now. Available: https://reliefweb.int/report/pakistan/pakistanearthquake-what-uk-did-and-what-were-doing-now [Accessed 29 Dec 2019].

42 Margesson R, Taft-Morales M. Haiti earthquake: crisis and response: Library of Congress Washington DC Congressional Research Service. Available: https://fas.org/sgp/crs/row/R41023. pdf [Accessed 29 Dec 2019].

43 Moberg L. Norwegian humanitarian response to natural disasters - Case of Haiti Earthquake January 2010. Available: https://www. norad.no/en/toolspublications/publications/2010/norwegianhumanitarian-response-to-natural-disasters---case-of-haitiearthquake-january-2010/ [Accessed 29 Dec 2019].

44 Guha-Sapir D, Kirsch T, Dooling S, et al. Independent review of the US government response to the Haiti earthquake. Available: https:// pdf.usaid.gov/pdf_docs/pdacr222.pdf [Accessed 29 Dec 2019].

45 OCHA. Turkey - Earthquake OCHA Situation Report No. 15 Available: https://reliefweb.int/report/turkey/turkey-earthquakeocha-situation-report-no-15 [Accessed 29 Dec 2019].

46 OCHA. Iran: UNDAC mission report following the Bam earthquake of 26 Dec 2003. Available: https://reliefweb.int/report/iran-islamicrepublic/iran-undac-mission-report-following-bam-earthquake-26dec-2003 [Accessed 29 Dec 2019].

47 USAID. Turkey - Earthquake Fact Sheet \# 6. Available: https:// reliefweb.int/report/turkey/turkey-earthquake-fact-sheet-6 [Accessed 29 Dec 2019].

48 SCDF. Tai Chung County earthquake (1999), 1999. Available: https://www.scdf.gov.sg/home/about-us/media-room/overseasmissions/tai-chung-county-earthquake-(1999) [Accessed $29 \mathrm{Dec}$ 2019].

49 Macintyre AG, Barbera JA, Petinaux BP. Survival interval in earthquake entrapments: research findings reinforced during the 2010 Haiti earthquake response. Disaster Med Public Health Prep 2011;5:13-22.

50 Schmidt S. Nepal earthquake - lessons learned and the way forward. Available: http://www.insarag.org/images/stories/Report Nepal_Earthquake_Lessons_Learned_and_Way_Forward.pdf [Accessed 29 Dec 2019].

51 Bartolucci A, Walter D, Redmond T. Comparative Review on the Cost-Effectiveness Analysis of Relief Teams' Deployment to Sudden-Onset Disasters. Prehosp Disaster Med 2019;34:415-21.

52 Peleg K. Notes from Nepal: is there a better way to provide search and rescue? Disaster Med Public Health Prep 2015;9:650-2.

53 Glassey S. Analysis of urban search and rescue markings applied following the 22 February 2011 Christchurch earthquake. J Search Rescue;2013:29-49.

54 DFID. Support to the United Kingdom search and rescue (UKISAR) for emergency response operations overseas (201518) development tracker business case and summary. Available: https://devtracker.dfid.gov.uk/projects/GB-1-205012/documents [Accessed 29 Dec 2019].

55 UK GOV. Humanitarian emergency response review London: UK Gov. Available: https://assets.publishing.service.gov.uk/ government/uploads/system/uploads/attachment_data/file/67579/ HERR.pdf [Accessed 29 Dec 2019]

56 Docherty S. Freedom of Information Request F2019-235, 2019

57 Allen J, Olson RS, Olson RA. Urban heavy rescue. Emerg Med Serv 1987;16:645-58.

58 Issues in intelligent robots for search and rescue. Unmanned ground vehicle technology II. International Society for Optics and Photonics, 2000.

59 UNDRO. Mexico: Earthquake Sep 1985 UNDRO Situation Reports 1 - 11. Available: https://reliefweb.int/report/mexico/mexicoearthquake-sep-1985-undro-situation-reports-1-11 [Accessed 29 Dec 2019].

60 Waeckerle JF. Disaster planning and response. N Engl J Med 1991;324:815-21.

61 Shepherd D, McBride D, Lovelock K. First responder well-being following the 2011 Canterbury earthquake. Disaster Prev Manag 2017;26:286-97.

62 Macintyre AG, Barbera JA, Smith ER. Surviving collapsed structure entrapment after earthquakes: a "time-to-rescue" analysis. Prehosp Disaster Med 2006;21:4-17. 
63 Cook ADB, Shrestha M. An assessment of international emergency disaster response to the $2015 \mathrm{Nepal}$ earthquakes. Int J Disaster Risk Reduct 2018;31:535-47.

64 IASC I-ASC. Response to the Humanitarian Crisis in Haiti following the 12 January 2010 Earthquake: Achievements, Challenges and Lessons to Be Learned. Geneva: Inter-Agency Standing Committee.2010

65 DFID. DFID project completion review - Haiti earthquake, 2010. Available: https://devtracker.dfid.gov.uk/projects/GB-1-201483/ documents [Accessed 29 Dec 2019].

66 Shenhar G, Adamcheck R, Hopmeier M. The need for international search and rescue (SAR) teams during an earthquake: Nepal case study. Dev Pract 2016;26:949-53.

67 Kelman I. Disaster diplomacy: how disasters affect peace and conflict. Abingdon: Routledge, 2012.

68 Koresawa A, Chubu Regional Bureau, Ministry of Land, Infrastructure, Transport and Tourism (MLIT), 2-5-1 Sannomaru, Naka-ku, Nagoya 460-8514, Japan. An analysis of international assistance based on lessons from the great East Japan earthquake. J Disaster Res 2014;9:653-64.

69 Kahane G, Everett JAC, Earp BD, et al. 'Utilitarian' judgments in sacrificial moral dilemmas do not reflect Impartial concern for the greater good. Cognition 2015;134:193-209.

70 UN. Promotion and protection of human rights in post-disaster and postconflict situations. Available: https://www.ohchr.org/ Documents/HRBodies/HRCouncil/AdvisoryCom/A-HRC-RES-22 16_en.pdf [Accessed 29 Dec 2019].

71 UN Human Rights Council. Final research-based report of the human rights Council Advisory Committee on best practices and main challenges in the promotion and protection of human rights in post-disaster and post-conflict situations. Available: https:// reliefweb.int/sites/reliefweb.int/files/resources/A_HRC_28_76_en. pdf [Accessed 29 Dec 2019].

72 Rice K, Felizzi MV, Hagelgans D. Human rights-based approach to disaster management: Valparaiso, Chile. J Hum Rights Soc Work 2017;2:117-27.

73 UNDRR. Sendai framework for disaster risk reduction. Available: https://www.unisdr.org/we/coordinate/sendai-framework [Accessed 29 Dec 2019].

74 Annan K. Facing the humanitarian challenge. towards a culture of prevention. Available: https://digitallibrary.un.org/record/285627? In=en [Accessed 29 Dec 2019].

75 Bilham R. Lessons from the Haiti earthquake. Nature 2010;463:878-9.

76 Abrams JI, Pretto EA, Angus D, et al. Guidelines for rescue training of the lay public. Prehosp Disaster Med 1993;8:151-6.

77 Petal M, Wisner B, Kelman I, et al. School seismic safety and risk mitigation. Encyclopedia of Earthquake Engineering 2015:1-20.

78 Kunreuther $\mathrm{H}$, Michel-Kerjan E. Natural disasters University of Pennsylvania. Available: https://www.copenhagenconsensus. com/sites/default/files/Natural+Disasters.pdf [Accessed 29 Dec 2019].

79 Petal M. Research Report: Afyon (Sultanda>-Bolvadin) February 6th, 2002 9: 03 am 6.0 Ms Earthquake Deaths and Injuries, Reconnaissance Study: Bogazici University, Disaster Preparedness Education Project. Istanbul, Turkey, 2003

80 Pretto EA, Angus DC, Abrams JI, et al. An analysis of prehospital mortality in an earthquake. Prehosp Disaster Med 1994;9:107-17.

81 FEMA. Community emergency response team. Available: https:// www.ready.gov/community-emergency-response-team [Accessed 29 Dec 2019].

82 Carr J, Jensen J. Explaining the pre-disaster integration of community emergency response teams (CERTs). Natural Hazards 2015;77:1551-71.

83 IFRC. Cost-benefit analysis of community-based disaster risk reduction. Available: https://www.preparecenter.org/sites/default/ files/cba guidance.pdf [Accessed 29 Dec 2019].

84 Yoshimura A, Satoh F, Akitomi S, et al. A study on the implementation strategy of urban search and rescue for Japan based on comparative surveys in the United States and the United Kingdom. Journal of Social Safety Science 2008;10:125-35.

85 Noji EK, Kelen GD, Armenian HK, et al. The 1988 earthquake in Soviet Armenia: a case study. Ann Emerg Med 1990;19:891-7.

86 Pretto EA, Ricci E, Klain M, et al. Disaster Reanimatology potentials: a structured interview study in Armenia. III. Results, conclusions, and recommendations. Prehosp Disaster Med 1992;7:327-37.

87 O'Brien PW, Mileti DS. Citizen participation in emergency response following the Loma Prieta earthquake. International Journal of Mass Emergencies and Disasters 1992;10:71-89.
88 Roy N, Shah H, Patel V, et al. The Gujarat earthquake (2001) experience in a seismically unprepared area: community hospital medical response. Prehosp Disaster Med 2002;17:186-95.

89 Petal M. Research report: causes of deaths and injuries in the August 17th, 1999 3: 02 am MW 7.4 Kocaeli earthquake. Istanbul, Turkey: Bogazici University, Disaster Preparedness Education Project, 2003.

90 Najafi I, Safari S, Sharifi A, et al. Practical strategies to reduce morbidity and mortality of natural catastrophes: a retrospective study based on Bam earthquake experience. Arch Iran Med 2009;12:347-52.

91 UNDRO. USSR earthquake Dec 1988 UNDRO situation reports 1-14. Available: https://reliefweb.int/report/armenia/ussrearthquake-dec-1988-undro-situation-reports-1-14 [Accessed 29 Dec 2019].

92 Guha-Sapir D, Carballo M. Disaster in turkey: lessons for health preparedness. Lancet 1999;354:1649-50.

93 Bishop J. Rapid study report on the International search and rescue response, to the Izmit earthquake: OCHA. Available: https://www.alnap.org/help-library/rapid-study-report-on-theinternational-search-and-rescue-response-to-the-izmit [Accessed 29 Dec 2019].

94 INSARAG. Turkey and Taipei earthquakes lessons learned meeting. Available: https://www.insarag.org/global-structures/ad-hoc-events [Accessed 29 Dec 2019].

95 Gillies AG, Anderson DL, Mitchell D, et al. The August 17, 1999, Kocaeli (Turkey) earthquake - lifelines and preparedness. Canadian Journal of Civil Engineering 2001;28:881-90.

96 USAID. Taiwan earthquake fact sheet \# 5. Available: https:// reliefweb.int/report/china-taiwan-province/taiwan-earthquake-factsheet-5 [Accessed 29 Dec 2019].

97 USAID. Taiwan earthquake fact sheet \# 6. Available: https:// reliefweb.int/report/china-taiwan-province/taiwan-earthquake-factsheet-6 [Accessed 29 Dec 2019].

98 O'Connor M. Taiwan earthquake. Australian Journal of Emergency Management 2000;15:31.

99 Chiu WT, Arnold J, Huang W, et al. Survey of international search and rescue teams after the Ji Ji earthquake in Taiwan. Ann Emerg Med 2001;37:733-4.

100 Goltz JD, Flores PJ, Chang SE, et al. Emergency response and early recovery. Earthquake Spectra 2001;17:173-83.

101 Mistry R, Dong W, Shah HC. Interdisciplinary observations on the January 2001 Bhuj, Gujarat earthquake. 2001. World Seismic Safety Initiative.

102 OCHA. Algeria - Earthquake OCHA Situation Report No. 6. Available: https://reliefweb.int/report/algeria/algeria-earthquakeocha-situation-report-no-6 [Accessed 29 Dec 2019].

103 SDC. Iran: Swiss aid for Bam - From rescue operations to longterm cooperation. Swiss Agency for Development and Cooperation. Available: https://reliefweb.int/report/iran-islamic-republic/ iran-swiss-aid-bam-rescue-operations-long-term-cooperation [Accessed 29 Dec 2019].

104 Movahedi H. Search, rescue, and care of the injured following the 2003 Bam, Iran, earthquake. Earthquake Spectra 2005;21:475-85.

105 Liu FL, Liu Zhi, Jin K. The role of international rescue teams after the 2008. Wenchuan Earthquake: Sichuan University, 2008.

106 vOSOCC. Eastern Sichuan Region - China 2008 vOSOCC Discussion Situation Overview. Available: https://vosocc.unocha. org/VODiscussions.aspx\#_top [Accessed 28 Jul 2019].

107 vOSOCC. Sumatra Indonesia 2009 vOSOCC Discussion - USAR Teams Information and Updates. Available: https://vosocc.unocha. org/VODiscussions.aspx\#t1059 [Accessed 28 Jul 2019].

108 Hopmeier MJ, Pape JW, Paulison D, et al. Reflections on the initial multinational response to the earthquake in Haiti. Popul Health Manag 2010;13:105-13.

109 FEMA. Haiti earthquake response quick look report. Available: https://publicintelligence.net/ufouo-fema-haiti-earthquakeresponse-report/ [Accessed 29 Dec 2019].

110 UN. Haiti Earthquake - Situation Updates. Available: https://www. un.org/News/dh/infocus/haiti/haiti_quake_update.shtml [Accessed 28 Jul 2019].

111 USAID. Haiti earthquake fact sheet 1. Available: https://pdf.usaid. gov/pdf_docs/PA00J2BP.pdf [Accessed 29 Dec 2019].

112 Bhattacharjee A, Lossio R. Evaluation of OCHA response to the Haiti earthquake. Available: https://www.unocha.org/sites/dms/ Documents/Evaluation\%20of\%200CHA\%20Response\%20to\% 20the\%20Haiti\%20Earthquake.pdf [Accessed 29 Dec 2019].

113 Kirsch T, Sauer L, Guha Sapir D. Analysis of the International and US response to the Haiti earthquake: recommendations for change. Disaster Med Public Health Prep 2012;6:200-8. 
114 Terradaily. World races to aid New Zealand quake rescue. Available: http://www.terradaily.com/reports/World_races_to_aid_New_ Zealand_quake_rescue_999.html [Accessed 29 Dec 2019].

115 McLean I, Oughton D, Ellis S, et al. Review of the civil defence emergency management response to the 22 February Christchurch earthquake. Available: https://www.civildefence.govt.nz/assets/ Uploads/publications/Review-CDEM-Response-22-FebruaryChristchurch-Earthquake.pdf [Accessed 29 Dec 2019].

116 Bookmiller RJ, Bookmiller KN. Donor countries as aid recipients: the USA, New Zealand and the lessons of Hurricane Katrina. Int $J$ Emerg Manag 2016;12:263-83.

117 OCHA. Japan: Earthquake \& Tsunami - Situation Report No. 2. Available: https://reliefweb.int/report/japan/japan-earthquaketsunami-situation-report-no-2 [Accessed 29 Dec 2019].

118 OCHA. Japan: Earthquake \& Tsunami - Situation Report No. 9. Available: https://reliefweb.int/report/japan/japan-earthquaketsunami-situation-report-no-9 [Accessed 29 Dec 2019].

119 vOSOCC. Nepal 2015 - USAR Coordination DiscussionSpreadsheet of International USAR Teams Working in Nepal Earthquake as of 02 May 1300hrs. Available: https://vosocc. unocha.org/VODiscussions.aspx\#_top [Accessed 28 Jul 2019].

120 Cook AD, Shrestha M, Htet ZB. The 2015 Nepal earthquake: implications for future international relief efforts. Available: https:// www.jstor.org/stable/resrep05910 [Accessed 29 Dec 2019].
121 DFID. DFID's Expenditure on humanitarian assistance 2009/10. Available: https://www.gov.uk/government/publications/dfid-sexpenditure-on-humanitarian-assistance-2009-10 [Accessed 29 Dec 2019].

122 UK GOV. Haiti earthquake - the UK response. Available: https:// www.gov.uk/government/news/haiti-earthquake-the-uk-response [Accessed 29 Dec 2019].

123 UK GOV. Earthquake in Japan. Available: https://www.gov.uk/ government/news/earthquake-in-japan [Accessed 29 Dec 2019].

124 DFID. Japan earthquake and tsunami response January 2010. Available: iati.dfid.gov.uk/iati_documents/3717061.odt [Accessed 29 Dec 2019].

125 USAID. Japan - Earthquake and Tsunami Fact Sheet \#4, Fiscal Year (FY), 2011. Available: https://reliefweb.int/report/japan/ japan-earthquake-and-tsunami-fact-sheet-4-fiscal-year-fy-2011 [Accessed 29 Dec 2019].

126 USAID. Japan - Earthquake and Tsunami Fact Sheet \#18, Fiscal Year (FY), 2011. Available: https://reliefweb.int/sites/reliefweb. int/files/resources/06.15.11\%20-\%20USAID-DCHA\%20Japan\% 20EQ\%20and\%20Tsunami\%20Fact\%20Sheet\%20\%2318.pdf [Accessed 29 Dec 2019].

127 USAID. Nepal earthquake - fact sheet \#24. Available: https://www. usaid.gov/nepal-earthquake/fy15/fs24 [Accessed 29 December 2019]. 